\title{
The Impact of the European Integration Process on the Banking System - an Overview
}

\author{
Bogdan Ilut, Alexandru Ioan Cuza University of Iasi, Romania
}

\begin{abstract}
In the last decade the European integration process was the main focuses of the European Union, as its completion could bring a huge step toward a fully integrated European Union. As the banking sector is the main channel for funding of the European economy, it has become now more clearly than ever that is integration is of the up more essence. The aim of this paper is to quantify the progresses registered by the main European Union's economies in the process of banking integration, as their example is generally followed by the other member states. First we underline the necessity of the European integration and the progress made using an extended literature review doublet by an analysis of the main indicators for the banking systems of these countries. We also present, in a non-exhaustive way, the main trends that have characterised the banking sectors of these countries in the last decade: diversification, vertical product differential and consolidation underlying their impact on the sectors architecture.
\end{abstract}

\section{Keywords}

Banking integration, European financial integration, diversification, consolidation

JEL Code: G21

\section{Introduction}

The euro has been one of the major factors for development in the last decade in the European Union. It has been also one of the most important social experiments carried out in the international arena. Even since the early stages of the Economic and monetary union there has been a fearful debate regarding its role in the European economic environment. One the one side there is a belief that the euro can enhance and bee the necessary ingredient in the process of the single market completion ${ }^{1}$. On the other hand many studies and economist have argued that the European Union as a whole lack the necessary premises for the developing and becoming an optimal currency area ${ }^{2}$.

An extensive research has been carried out in order to establish the impact of the euro on the different sectors of the European economy like: trade, industry or financial markets. Even if the researches carried out mostly find positive impact and transformations as a result of the euro adaptation. Unfortunately most of the studies are unable to identify clearly the exact impact, especially in the case of financial integration, as there are many transformations and structural reform that are having a direct impact on the economical environment of a country that wants to adopt the euro.

One of the main sectors that were affected by this was the banking sector. Over the last decade banking markets across the European Union have become increasingly integrated. Even in the light of these trends there are still barriers to full integration, these being more

\footnotetext{
${ }^{1}$ see Dolores Report - * (1989) Report on economic and monetary union in the European Community, Luxemburg. 2 see Mundell, R., (1961) A Theory of Optimum Currency Areas, American Economic Review, 51 (4): $509-517$.
} 
obvious on the retail banking segment. European integration and directly banking integration pose implications for systemic risks while raising even more challenges for the currency supervision framework. As a result of these changes, banks in the European Union have responded by adopting and implementing strategies of diversification, vertical product differentiation or consolidation approaches.

\section{Integration of the European banking industry}

Our analysis is focused on the big five economies of the European Union. These belong to Germany, United Kingdom, France, Italy and Spain ("big five"). These countries also have the largest populations on the European Union which combined with their economic development provides the best ground for underlying the evolution and mutations in the banking sector as a result of European financial integration.

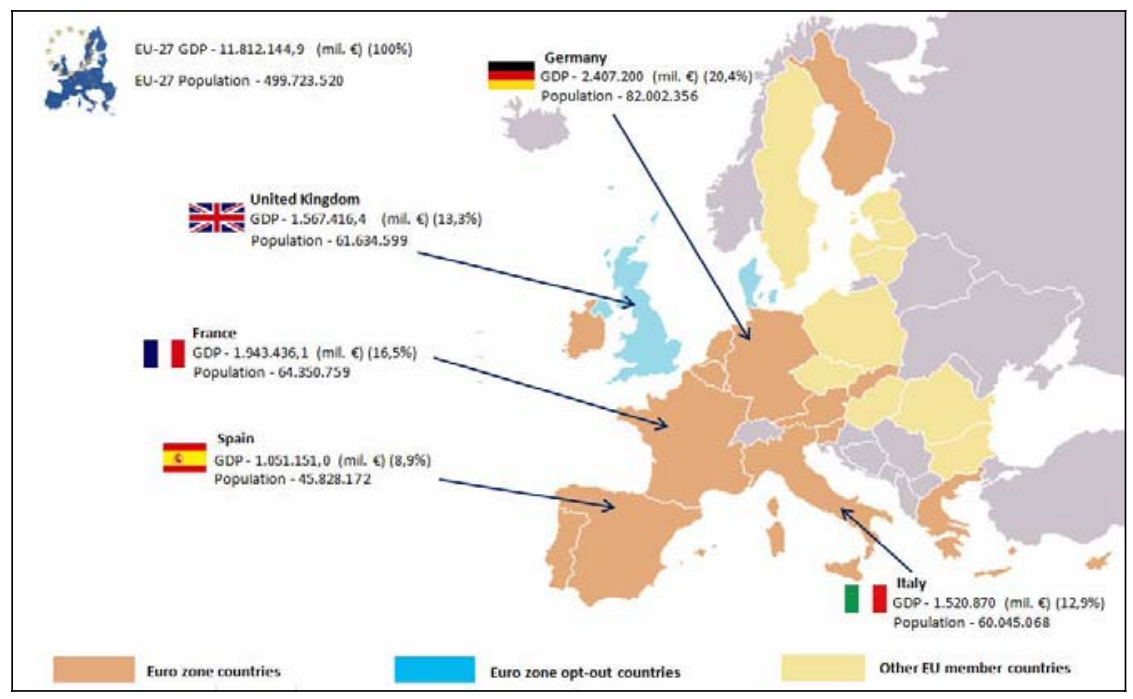

Figure. 1. Characteristics of the "Big Five" economies of the European Union in 2009 Source: Own simulation based on Eurostat data

Between 1997 and 2009 the total number of bank in the European Union has dropped from 9624 to 8348, in the context of EU extension from 15 countries to 25 in 2004 and then to 27 in 2007. In the "big five" economies this trend has manifested also, with the total number of banks dropping from 6540 to 4402 .

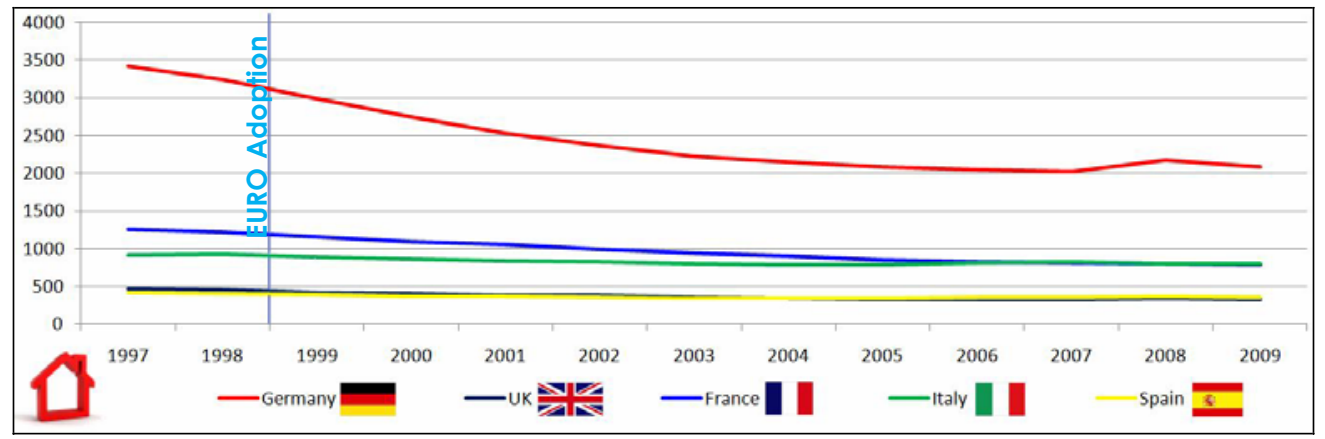


Figure. 2. Evolution of the number of banks in the "Big Five" economies of the European Union between 1997 and 2009

Source: Own simulation based on Eurostat and European Banking Federation data

On the other hand there was a raise on the total assets of bank in the same period, both at European level and also in the case of the big five economies. This growth reflects the effectiveness of deregulation and the single market program in bringing about the end of "repressed" banking systems. ${ }^{3}$

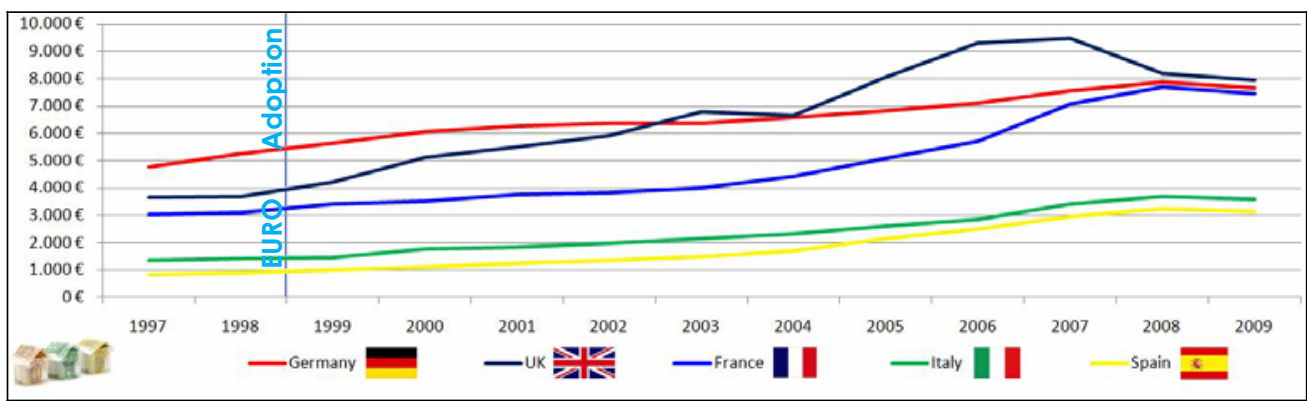

Figure. 3. Evolution of the assets held by the banks in the "Big Five" economies of the European Union between 1997 and 2009

Source: Own simulation based on Eurostat and European Banking Federation data

Mean while the employment of the banking system has been somehow stable, decreasing with only about 5\% in the European Union between 1997 and 2009. The evolution in the "big five" economies has been very different, with a relative increase in Italy and Spain and a diminishing in employment in Germany, France and the United Kingdom.

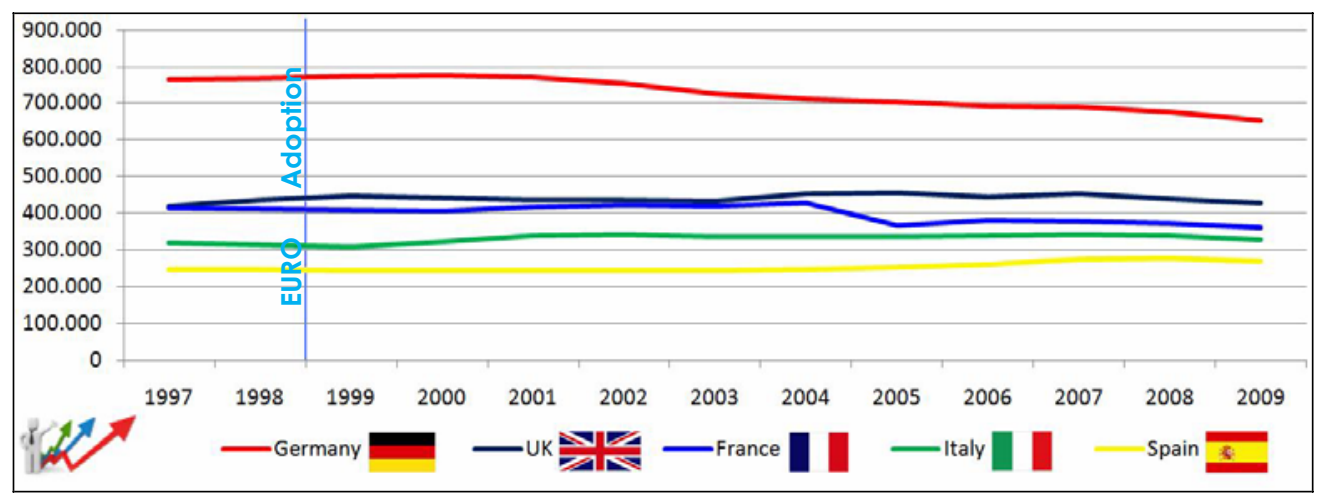

Figure. 4. Evolution of the employment by the banking sector in the "Big Five" economies of the European Union between 1997 and 2009

Source: Own simulation based on Eurostat and European Banking Federation data

The data on the concentration of the banking sector (the share of the first five banks assets in total banking sector assets - CR5 indicator) presents a rather interesting situation. There is a relative stability regarding this indicator. This is possible because on the one hand the deconcentration that comes natural as a side effect of increase competition on open market in

\footnotetext{
${ }^{3}$ Dermine, J., (2006) European banking integration: Don't put the cart before the horse, in: Financial Institutions, Markets and Money 15, 57-106.
} 
the traditional loan business and on the other hand is offset by the tendency of concentration that characterises non-traditional banking activities ${ }^{4}$.

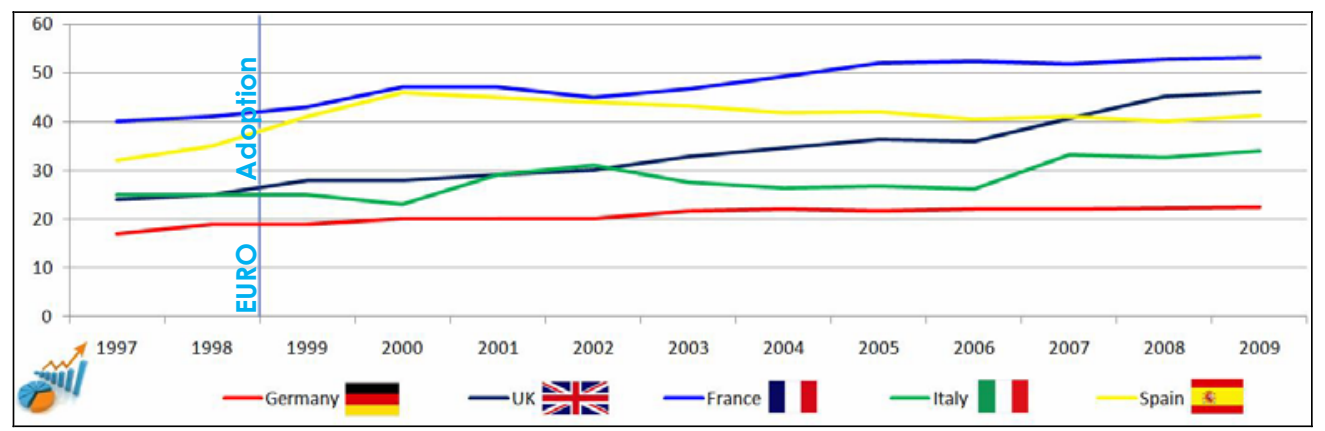

Figure. 5. Evolution of the CR5 indicator in the "Big Five" economies of the European Union between 1997 and 2009

Source: Own simulation based on Eurostat and European Banking Federation data

It is evident that the complexity of the European financial integration in general and that of the banking sector in particular runs more deeply than the raw dates presented here can summarise ${ }^{5}$. An argument in this favour is represented by the liberalisation of and the integration of the European financial markets and payment systems, which have put an enormous pressure on the banking system. As a response to the ever growing competition that they must face, banks have opted to diversify their activities outside their traditional line of business and entered non-interest earning segments like: insurance and mutual fund sales, private banking and asset management. At the same time banks have saw fit to re-engineer their value chain by increasing the rate of their loans portfolio securitization. Overall, financial innovation has lead European banks to offer a wider range of products and services that ever before, conducting an ever greater part of their businesses off balance-sheet. As a result of this transformation the differences between banks and non-bank financial intermediaries has become blurrier than ever ${ }^{6}$.

These transformations have been reflected also in the traditional way of banking business, mainly in the loan sector. Here, after an enhancement of the loaning as a result of euro adaptation, the banking sector of the "big five" has registered a rather slow pace in increasing the volume of loans (both to business and retail).

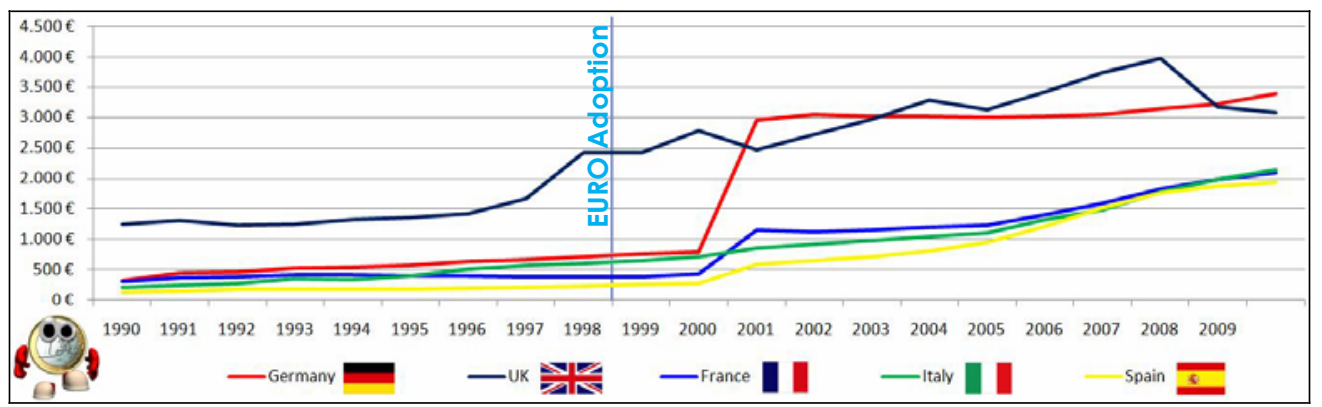

${ }^{4}$ Carbo, S., Fernandez, J., (2005) The determinants of bank margins: The effects of diversification, FUNCAS working paper.

${ }^{5}$ Barros, P.P., Berglof, E., Fulghierri, J., Gual, J., Mayer, C., Vives, X., (2005) Integration of European Banks: The Way Forward, Centre for Economic Policy Research, London.

${ }^{6}$ Rajan, R.G., Zingales, L., (2003) Banks and markets: The changing character of European finance, in: Gaspar, V., Hartmann, P., Sleijpen, O. (Eds.), Proceedings of the 2nd ECB Central Banking Conference on the Transformation of the European Financial System, European Central Bank, Frankfurt. 
Figure. 6. Evolution of the loans granted by the banks in the "Big Five" economies of the European Union between 1990 and 2009

Source: Own simulation based on Eurostat and European Banking Federation data

The integration of the European financial markets and the banking system in particular has been sustained by a series of legislative act aimed at preparing, allowing and enhancing the integration of these sectors.

Table no. 1. European legislation that had an impact on the integration of the EU banking and financial sectors

\begin{tabular}{|c|c|}
\hline Year & Legislative piece \\
\hline 1977 & First Banking Directive \\
\hline 1988 & Basle Capital Adequacy Regulation (Basle I) \\
\hline 1988 & Directive on Liberalization of Capital Flows \\
\hline 1989 & Second Banking Directive \\
\hline 1992 & Large Exposures Directive \\
\hline 1993 & Investment Services Directive \\
\hline 1994 & Directive on Deposit Guarantee Schemes \\
\hline 1999 & Financial Services Action Plan (FSAP) \\
\hline 2000 & Consolidated Banking Directive \\
\hline 2000 & Directive on e-money \\
\hline 2001 & Directive on the Reorganisation and Winding-Up of Credit Institutions \\
\hline 2001 & Regulation on the European Company Statute \\
\hline 2002 & Financial Conglomerates Directive \\
\hline 2004 & New EU Takeover Directive \\
\hline $2005-2010$ & White paper on Financial Services Policy \\
\hline $2006-2008$ & Capital Requirements Directive (Basle II) \\
\hline
\end{tabular}

Despite this sustained legislative drive at European level, regarding the harmonization and integration of banking sector in particular, there are still barriers in the way of a fully integrated system, as stock markets have achieved a higher degree of integration than the banking sector as many researches show ${ }^{7}$.

The barriers that are arising come from different areas like: national economic conditions and characteristics, culture, language barriers and none the least from fiscal and legal system ${ }^{8}$. Taking into consideration these barrier there are several way in which a bank can expand its operations abroad, in other European Union member states?:

$\checkmark$ one approach is to open a branch or a subsidiary in the countries in which it wishes to expend;

$\checkmark$ another is to offer cross-border services and products directly through the European financial passport;

$\checkmark \quad$ or it could enter a strategic partnership with another bank that already operates in that particular country, taking in to consideration the option of locating different functions of

\footnotetext{
${ }^{7}$ Cappiello, L., Ho rdahl, P., Kadareja, A., Manganelli, S., (2006) The impact of the euro on financial markets, European Central Bank working paper no. 598.

${ }^{8}$ Berger, A.N., Dai, Q., Ongena, S., Smith, D., (2003) To what extent will the banking system become globalized? A study of bank nationality and reach in 20 European countries, Journal of Banking and Finance, 27, 383-415.

${ }^{9}$ HM Treasury, (2005) Supervising financial services in an integrated European single market: A discussion paper, HMSO, London.
} 
its business in different states - the ones that are offering the best environment for that particular function.

Even if the integration of the European banking system is far for its completion, it is obvious that the European bank have a wide range of strategies available to them in order to extend their business at a European level. In this regard, the integration of the banking system as a whole has a direct effect on its stability and exposure to systemic risks. Before integration, the evolution of the national banking system of a particular country is positively correlated with is macroeconomic performances. As the system becomes more integrated, banks tend to geographically diversify their business and the correlation with a specific country where it operates tends to diminish. So the exposure of a specific bank or a national banking system to country-specific macroeconomic shocks is reduced. On the other hand, deepening the integration process is leading to a shift in correlation from country specific to European specific shock, exposing a wider segment of bank to shocks ${ }^{10}$, a good example of the in this case being the 2007-2010 financial crises, which spread all across Europe through the integrated financial and banking system.

There is no doubt that the European integration process in general and the construction of an integrated banking system have help in the achievement of the facts presented above. Nevertheless, the degree to which the ideal of an integrated European banking market has yet been realized remains open to debate.

\section{The main trends of the European banking system}

As a response to the structural changes in the European banking market architecture the main European banks have responded through an aggressive expansion strategy that aimed their development either thru internal development or through merger and acquisition. This strategy has enabled banks to grow in a relative short period of time, taking full advantage of the new integrated European banking environment, which in turned allowed them to obtain large economies of scale. These economies were obtained through a better management of variable costs like labour and a diminishing in the percentage of operational inefficiencies, based on a diversification of the revenue sources.

A very important role in the growth strategies and the diversification of revenues played the ability of bank to expend their cross-border activities. The tendency for much cross-border European banking activity to take place through the creation of subsidiaries rather than branches points to the continued existence of significant barriers to full market integration ${ }^{11}$. In general, the impact of an increase in market size on the growth of individual firms depends on industry product and technological characteristics.

Accordingly, the potential for management strategy to influence performance may be high if there is scope for vertical product differentiation and the posibility for further consolidation. Consolidation has contributed significantly to the reduction in the number of banks operating in the EU-27 countries, as we have showened earlier. Empirical evidence on the impact of bank mergers in Europe is mixed. There is some event study evidence that stock markets prefer focused mergers to those that involve diversification ${ }^{12}$.

The empirical literature on mergers and acquisitions has used either a event study methodology and stock price data in oreder to underline the investor expectetion in regard to the merger or has done a before and after nanlysis of the performance that the banks has registred usig accounting data or performance ratio indicators. Until now unfortunetly no reserch was undertaken usign an integrted approche of the two methods. It is more than

\footnotetext{
${ }^{10}$ Gropp, R., Moermann, G.A., (2004) Measurement of contagion in banks equity prices, Journal of International Money and Finance, 23, 405-419.

${ }^{11}$ Barros, P.P., Berglof, E., Fulghierri, J., Gual, J., Mayer, C., Vives, X., (2005) Integration of European Banks: The Way Forward, Centre for Economic Policy Research, London.

${ }^{12}$ Beitel, P., Schiereck, D., Wahrenburg, M., (2004) Explaining M\&A success in European banks, European Financial Management 10, 109-140.
} 
obvous that further investigation must be done in order to establish the full impact of consolidation and vertical differentiation on the integrated european banking sector.

\section{Conclusions}

Even if there has a great deal of progress registered in the process of European banking integration there is still a long road ahead. There still exist multiple barriers that are preventing free access to the market, partisan behaviour from both regulator and authorities deprives participants of equal treatment and never the least, and systemic events like the current financial crisis tend to bring back nationalist behaviours.

The process toward a fully integrated banking sector is multi-faceted and ongoing challenge. But more importantly researches must come with a clear answer regarding maximal degree of integration that can be reached on such a dynamic and complex sector, like the banking one. We believe that future studies regarding these matters will provide the necessary blue print for the deepening of the integration in the European banking sector and the ultimate goal, that of a fully working European financial system that will ensure the European economy the necessary resources for a sustainable development.

\section{Biography}

1. * (1989) Report on economic and monetary union in the European Community, Luxemburg.

2. Barros, P.P., Berglof, E., Fulghierri, J., Gual, J., Mayer, C., Vives, X., (2005) Integration of European Banks: The Way Forward, Centre for Economic Policy Research, London.

3. Beitel, P., Schiereck, D., Wahrenburg, M., (2004) Explaining M\&A success in European banks, European Financial Management 10, 109-140.

4. Berger, A.N., Dai, Q., Ongena, S., Smith, D., (2003) To what extent will the banking system become globalized? A study of bank nationality and reach in 20 European countries, Journal of Banking and Finance, 27, 383-415.

5. Cappiello, L., Ho“rdahl, P., Kadareja, A., Manganelli, S., (2006) The impact of the euro on financial markets, European Central Bank working paper no. 598.

6. Carbo , S., Fernandez, J., (2005) The determinants of bank margins: The effects of diversification, FUNCAS working paper.

7. Dermine, J., (2006) European banking integration: Don't put the cart before the horse, in: Financial Institutions, Markets and Money 15, 57-106.

8. European Central Bank, (2008) EU banking structures, ECB, Frankfurt am Main.

9. European Central Bank, (2009) EU banking sector stability, ECB, Frankfurt am Main.

10. European Central Bank, (2009) Financial integration in Europe, ECB, Frankfurt am Main.

11. European Central Bank, (2009) Financial stability review, ECB, Frankfurt am Main.

12. Gropp, R., Moermann, G.A., (2004) Measurement of contagion in banks equity prices, Journal of International Money and Finance, 23, 405-419.

13. HM Treasury, (2005) Supervising financial services in an integrated European single market: $A$ discussion paper, HMSO, London.

14. Mundell, R., (1961) A Theory of Optimum Currency Areas, American Economic Review, 51 (4): 509-517.

15. Rajan, R.G., Zingales, L., (2003) Banks and markets: The changing character of European finance, in: Gaspar, V., Hartmann, P., Sleijpen, O. (Eds.), Proceedings of the 2nd ECB Central Banking Conference on the Transformation of the European Financial System, European Central Bank, Frankfurt.

16. http://epp.eurostat.ec.europa.eu/portal/page/portal/statistics/themes

17. http://www.ebf-fbe.eu/index.php?page=statistics 